1Dr. Sharmin Sultana Junior consultant (gynae and obs) 50 bedded hospital Rupganj, Narayanganj

${ }^{2}$ Dr. Nasreen Sultana Junior consultant (gynae and obs) 50 bedded hospital Rupganj, Narayanganj

${ }^{3}$ Dr. SK. Ashraf Ullah Associate. Professor(c.c)(Orth.) Northern International Medical College, Dhaka

${ }^{4}$ Dr. Salma Akter Walida Junior consultant (gynae and obs) 50 bedded hospital Rupganj, Narayanganj

${ }^{5}$ Dr. Parul Akter

Asst. Professor (gynae and obs) SSMC\&MH

${ }^{6}$ Dr. Fakhruddin Ahmed Junior consultant (Anesthesia) 50 bedded hospital Rupganj, Narayanganj

\section{Correspondence}

Dr. Sharmin Sultana

Junior consultant (gynae and obs) 50 Bedded Hospital, Rupganj,

Narayanganj

E-mail : sharminmita86@gmail.com

\title{
Study of Primary Amenorrhea with etiology in out door patient of Rupganj Upazilla Health Complex
}

\author{
S Sultana ${ }^{1}$, N Sultana ${ }^{2}$, S A Ullah ${ }^{3}$, S A Walida ${ }^{4}$, P Akter ${ }^{5}$, F Ahmed ${ }^{6}$
}

\begin{abstract}
Background : Amenorrhea means without menstruation. Primary Amenorrhea is the absence of menstruation by 16 years of age in the presence of normal secondary sexual characteristics or by 14 years of age if secondary sexual characteristics have not developed.
\end{abstract}

Objectives : To explore the prevalence of Primary Amenorrhea with etiology in outdoor patient with limited investigation sources

Methods : This was a cross sectional study conducted at Rupganj Upazila Health Complex (UHC) from January 2014 to June 2016. During this period total 2500 patients attended at Gynae out patient department (OPD). Among them 45 patients was sorted out with Primary amenorrhea. History and physical examination was done for presence or absence of secondary sexual characteristics, external genital abnormalities. Investigations were ultrasonogram (USG), Hormonal test were Follicle stimulating Hormone (FSH), Lutilizing hormones (LH), Serum Prolactin, Thyroid Stimulating Hormone. Karyotyping done. Data were analysed by using SPSS version 20.

Result : In our study prevalence of Primary Amenorrhea was 1.8\%. Among them infantile uterus was $17.78 \%$, imperforated hymen was $13.33 \%$. Turner mosaic $11.4 \%$, mullarian agenesis $6.66 \%$, gonadal agenesis-4.45\%. hypothyroid $8.89 \%$, hyperprolactenemia- $8.89 \%$, and $11.11 \%$ patients were with positive progesterone challenge test without anatomical and hormonal abnormalities.

Conclusion : Considering the study result, Infantile uterus was the most prevalent etiological factor of amenorrhoea followed by imperforated hymen and Turner mosaic.

Key word : Primary Amenorrhea, infantile uterus, imperforated hymen, Turner mosaic.

DOI: http://dx.doi.org/10.3329/nimcj.v9i2.38911

Northern International Medical College Journal Vol. 9 No. 2 January 2018, Page 300-303

\section{Introduction}

Primary Amenorrhea is one of the common reproductive disorder affecting females. It leads to the absence of menarche in the reproductive age group in females. Reported incidence of Primary Amenorrhea is $1-3 \%$ of women in reproductive age group. There are many causes which leads to Primary Amenorrhea including genetic aberrations. Various factors such as anatomical, genetic and hormonal factors reported to influence Primary Amenorrhea. ${ }^{1}$ The recommended evaluation for amenorrhea aimed to divide the reproductive system into components like genital outflow tract, uterus, the ovary, the pituitary and to asses the functional integrity of each, starting at the lowest level (the genital outflow tract) and upto the highest levels (hypothalamus).

The most common etiology of Primary Amenorrhea is- gonadal dysgenesis (40\%), Hypothalamic Amenorrhea (30\%). The genital examination is abnormal in $15 \%$ of patients with Primary Amenorrhea ${ }^{2}$. In rare condition more than one component of hypothalamus- pituitaryovary (HPO) axis and genital tract are affected. ${ }^{2}$ Other than each 20\% hypoprolactenemea and $30 \%$ chance of weight related Amenorrhea. ${ }^{3}$

The etiologic factors of primary amenorrhoea $^{4}$

\section{Group I- End organ failure/ outflow tract} obstruction

a) Mullerian agenesis

b) Transverse vaginal septum 
c) Tuberculous endometritis

d) Male pseudo hermaphroditism- complete testicular feminization.

\section{Group II- Gonadal failure}

a) Gonadal dysgenesis (46XX, 45XO, Mosaic)

b) Agonadism

c) Post chemotherapy

\section{Group III- Pituitary cause}

a) Hyperprolactinemia

b) Prolactinoma

\section{Group IV}

a) Hypogonadotropic hypogonadism

b) Hypothalamic dysfunction

\section{Group V}

a) Primary hypothyroidism

b) Congenital adrenal hyperplasia

c) Androgen secreting tumour

Secondary amenorrhea is absence of menstruation for their normal cycle or for six months. ${ }^{5}$

Physiological Amenorrhea occurs before puberty, during pregnancy, lactational period and during menopause. ${ }^{5}$

Pathological Amenorrhea are of 3 types-

- Amenorrhea without secondary sexual characterictics.

- Amenorrhea with secondary sexual characteristics and anatomic abnormalities.

- Amenorrhea with secondary sexual characteristics and nonanatomic cause.

For majority of pubertal girl's menstruations is the final result of series of events which result in sexual maturity. Maturation of hypothalamus through several years of late childhood begins a cascade of events of the normal menstruatal cycle and menstruation. ${ }^{6}$

First and foremost, it is imperative to rule out pregnancy. Additional diagnosis of Primary Amenorrhea usually result from genetic or anatomic abnormality. The relative prevalence of Primary Amenorrhea includes hypergonadotropic hypogonadism $(48.5 \%)$, hypogonadotropic hypogonadism (27.8\%) and eugonadism (pubertal delay) with normal gonadotrophin $(23.7 \%)^{7}$

The hypergonadotropic hypogonadism category includes (a) patients with abnormal sex chromosome (i.e. turners syndrome) who make up $29.7 \%$ of all Primary Amenorrhea cause and those (b) Patient with normal sex chromosomes. The later group includes both patients who are $46 \times x(15.4 \%)$ and those $46 x y(3.4 \%){ }^{8}$ hypogonadotropic hypogonadism includes

(a) Congenital abnormalities

(b) Endocrine disorders

(c) Tumor

(d) Systemic illness(2.6\%)

(e) Eating disorder(2.3\%).

a) Congenital abnormalities that can cause hypogonadotropic hypogonadism include the following

Isolated GnRh deficiency (8.3\%)

Forms of hypopituitarism (2.3\%)

Congenital CNS defect $(0.8 \%)$

Constitutional delay (6\%).

b) Endocrine disorders that can cause hypogonadotropic hypogonadism includes-

Congenital Adrenal Hyperplasia (CAH) $(0.8 \%)$

Cushing Syndrome $(0.4 \%)$

Hyperprolactinemia (1.9\%)

c) Tumors that can cause hypogonadotropic hypogonadism includes-

Unclassified pituitary adenoma $(0.8 \%)$

Craniopheryngioma (1.1\%)

Unclassified malignant tumor $(0.4 \%)$

Eugonadism may result from anatomic abnormalities includes congenital absence of the uterus and vagina (CAUV-16\%) and Cervical Artesia (0.4\%) intersex disorders include androgen insensitivity $(1.5 \%), 17$ ketoreductase defficiency $(0.4 \%)$ and inappropriate feedback (5.3\%). ${ }^{9}$

We conducted this study to evaluate the etiology of primary amenorrhoea in women attending at a Primary health care centre in Bangladesh.

\section{Methods}

The study design was descriptive cross sectional and conducted at Rupganj Upazilla Health Complex (UHC) from 2014 January to June 2016. Total 2400 patients were attended at Gynae OPD among them 45 patients with primary amennorrhoea were sorted out following nonprovability purposive sampling.

Then proper case history was taken and physical examination was done for presence or absence of secondary sexual characteristics, external genital abnormalities, and several laboratory investigations (ultrasonogram (USG), Hormonal test were Follicle stimulating Hormone (FSH), Lutilizing hormones (LH), Serum Prolactin, Thyroid Stimulating Hormone. 
Karyotyping) were done from Bangladesh Institute of Research and Rehabilitation in Diabetes, Endocrine and Metabolic Disorder (BIRDEM) and Bangabandhu Sheik Mujib Medical University (BSMMU). Hormonal assay done to sort out endocrine disorder. Ultrasonogram (USG) was done to find out any abnormalities of internal genital organ- infantile uterus, Mullerian agenesis, gonadal agenesis, imperforated hymen etc. Karyotyping was done to find out chromosomal anomaly.

Those patient who were within normal BMI and presence of secondary sexual characteristics and normal biochemical findings were given progesterone challenge test

Data collected from individual history and data sheet. Prior to data collection ethical clearance was taken from authority and informed consent was taken from patients. Confidentiality and privacy was maintained while data collection was done. Data were cleaned, edited and analyzed by using SPSS version 20 . The frequency was calculated and percentage was done to find out the prevalence of etiology.

\section{Result}

Among 45 patients 43 patients (95.55\%) was found with secondary sexual characteristics (Breast development, Pubic and axillary hair and with normal external genitalia). 2 (4.45\%) patients found without secondary sexual characteristics but with normal external genitalia. (Table-1)

Table I : Secondary sexual Characteristics

$\begin{array}{lcc}\text { Secondary Sexual Characteristic } & \text { Frequency } & \text { Percentage } \\ \text { Present } & 43 & 95.55 \% \\ \text { Absent } & 02 & 04.45 \%\end{array}$

USG showed that Infantile uterus is about $<5 \mathrm{~cm}$ in length but gonad present in $17.78 \%$, Uterus and Adenexa present but haematocolpas, haematometra that is imperforated hymen 6 (13.33) patients out of 45 patients. About 5(11.11\%) patients are found with streak gonad/complex gonadal structure. Gonad present but uterus absent i.e Mullerian agenesis 3(6.66\%). But gonad absent uterus present in $2(4.45 \%)$ patients. About $21(46.67 \%)$ patients are found with normal uterus and normal gonad on USG finding. ( Table-II)

\section{Table II : USG}

$\begin{array}{lcc}\text { USG finding } & \text { Frequency } & \text { Percentage } \\ \text { Normal internal genitalia with imperforated hymen } & 06 & 13.33 \% \\ \text { Infantile uterus } & 08 & 17.78 \% \\ \text { Mullerian agenesis } & 03 & 06.66 \% \\ \text { Gonadal agenesis } & 02 & 04.45 \% \\ \text { Streak/ complex gonadal stricture } & 05 & 11.11 \% \\ \text { Normal uterus with normal gonad } & 21 & 46.67 \%\end{array}$

Result on hormonal analysis showed that 22 (48.89\%) had normal level. 5 patients had increased patients FSH, LH increased in 10 (22.22\%) patients, increased TSH in 4(08.89\%) patients, increased serum Prolactin level in $4(08.89 \%)$ patients. (Table III)

Table III : Hormonal Analysis

$\begin{array}{lcc} & \text { Frequency } & \text { Percentage } \\ \text { Within Normal } & 22 & 48.89 \% \\ \text { FSH-- increased } & 05 & 11.11 \% \\ \text { LH-- increased } & 10 & 22.22 \% \\ \text { TSH- increased } & 04 & 08.89 \% \\ \text { S.Prolactin- increased } & 04 & 08.89 \%\end{array}$

Turner mosaic 45XO found in $7(38.89 \%)$ and $11(61.11 \%)$ patients with 46XX karyotype (Karyotyping done in 18 patients) (Table IV)

\begin{tabular}{|c|c|c|}
\hline Karyotype & Frequency & Percentage \\
\hline 45XO-(Turner's mosaic) & 07 patients & $(38.89 \%)$ \\
\hline $46 X X-$ & 11 patients & $(61.11 \%)$ \\
\hline
\end{tabular}

Among 45 patients of Primary Amenorrhea those with all hormonal, USG finding were normal, progesterone challenge test was positive. They had normal menstrual flow after withdrawing of 7 days progesterone orally.

All these patients 45 family history was negative for any gynecological issue.

\section{Discussion}

At Rupganj UHC from January 2014 to June 2016 about 2500 patients attended at Gynae OPD. Among them 45 patients was sorted out with Primary amenorrhea prevalence was $1.8 \%$.

In our study infantile uterus was $17.77 \%$, mullarien agenesis$6.67 \%$, gonadal agenesis-4.45\%. Study of Primary Amenorrhea by Elisabeth H. Quint, M.D. and Yolanda R. Smith MD., MS showed similar result. On USG examination their study revealed infantile uterus with normal ovaries and FSH and Estradiol leves were normal. ${ }^{7}$

In our study on ultrasonogram finding revealed that uterus and gonad present but haematocolpos and haematometra with imperforated hymen found in $13.33 \%$ and complex gonad/ streak gonad in $11.11 \%$ cases. On the other hand Firouzeh Ghaffari, Fatemeh Keikha and Arezoo Arabipoor reported Primary Amenorrhea with two etiologies-Hypothalamic Amenorrhea and transverse vaginal septum with no haematocolpos. ${ }^{3}$

The current study revealed hormonal analysis of FSH, LH, Prolactin, TSH were normal in $48 \%$ cases and rest cases showed increased level of different hormon. Similar result was found in study done by Z. Nazir et al. ${ }^{10}$

In our study, karyotyping was done in 18 patients. Among them 
7(38.89\%) patients were 45XO and 11(61.11\%) patients were 46XX. In a study by Amduha et al showed that 305 cases were confirmed to have chromosomal abnormalities. ${ }^{11}$

Among 45 patients of Primary Amenorrhea 5(11.11\%) with all hormonal, USG finding normal and progesterone challenge test was positive, that is, they have normal menstrual flow after withdrawing of 7 days progesterone orally. All of the patients (45) family history was negative for any gynaecological issues. A study by M. Behera was also found similar result. ${ }^{9}$

\section{Conclusion}

Considering the study result, Infantile uterus was the most prevalent etiological factor leading to amenorrhoea followed by imperforated hymen and Turner mosaic.

\section{References}

1. A Case of Primary Amenorrhea with $46+X Y$ genotype from Kashmir Valley Shahid Mudassir, aga syed Sameer, and Mushtaq A. Siddiqi- Indian J. Hum Genet. 2013 Jul-Sep, 19(3): 360-362. Doi: 10.4103/0971-6866.120816.

2. Professional Verssion- by JoAnn V. Pinkerton, MD. University of Virginia Health System.

3. A Rare Case of Primary Amenorrhea with Two Etiologies, Hypothalamic Amenorrhea, Transverse Vaginal septum, and No Hematocolpos- Firouzeh Ghaffari ${ }^{1}$, Fatemeh Keikha ${ }^{2,3}$, and Arezoo arabipoor ${ }^{1}-$ Hindawi Publishing
Corporation, Case reports in Obstetrics and Gynecology, Volume 2015(2015), Article ID 989123, 3 pages.

4. Jeff Coates' Principles of Gynecology, $7^{\text {th }}$ Edition, page-579.

5. Medscape- Updated: Mar 02,2016, Author: Kenneth M Bielak, MD; Chief Editor: Richard scott Lucidi, MD, FACOG, page-6/19.

6. Chapter-38, Primary Amenorrhea, D Keith Edmonds page-386, $7^{\text {th }}$ Edition, Dewhurst's text book of Obstetrics and Gynecology.

7. Primary Amenorrhea in a Teenager by Elishbeth $\mathrm{H}$. Quin $\mathrm{t}, \mathrm{MD}$, and Yolanda R. smith, MD, MS. Vol. 107, No.2, Part 1, February 2006.

8. Practice Committee of the American Society for Reproductive Medicine, "Current evaluation of amenorrhea," Fertility and Sterility, vol. 90, no. 5, supplement, pp. S219-S225, 2008. View at Google Scholar.

9. M. Behera, G. Couchman, D. Walmer, and T. M. Price, "Mullerian agenesis and thrombocytopenia absent radius syndrome: a case report and review of syndromes associated with Mullerian agenesis," Obstetrical and Gynecological Survey, vol. 60, no. 7, pp. 453-461, 2005. View at Publisher · View at Google Scholar · View at Scopus.

10. Z. Nazir, R. M. Rizvi, R. N. Qureshi, and Z. S. Khan, "Congenital vaginal obstructions: varied presentation and outcome," Pediatric Surgery International, vol. 22, no. 9, pp. 749-753, 2006. View at Publisher ' View at Google Scholar · View at Scopus.

11. ACOG Committee on Adolescent Health Care, "ACOG Committee Opinion No. 355: vaginal agenesis: diagnosis, management, and routine care," Obstetrics \& Gynecology, vol. 108, no. 6, pp. 1605-1609, 2006. View at Google Scholar. 